\title{
Aproximação teórico-metodológica aos processos de codificação de Carreiras Profissionais
}

Aproximación teórico-metodológica a los procesos de codificación de Carreras Profesionales

Theoretical and methodological approach to codification procedures of Professional Careers

\author{
Clara Selva Olid \\ Universidad Autónoma de Barcelona - Espanha
}

Rose Capdevila

The Open University - Reino Unido

Miguel A. Sahagún Padilla

Universidad Autónoma de Aguascalientes - México

Francisco Javier Rubalcaba-Coyaso

Universidad Autónoma de Aguascalientes - México

Alba Navarrete Briansó

Universidad Autónoma de Barcelona - Espanha

\section{RESUMO}

As carreiras profissionais constituem um tema de estudo recorrente dentro das ciências sociais. $\mathrm{O}$ objetivo deste artigo é apresentar uma revisão da literatura existente sobre o tema com o objetivo de identificar como se estudam as carreiras, trajetórias e transições profissionais, que aproximações metodológicas se utilizam e a que temáticas se associam a fim de conhecer os modelos conceptuais e metodológicos em que se sustentam. Para este fim, foi feita uma pesquisa em diferentes bancos de dados indexados, dando origem a uma seleção de 66 artigos que tratam do fenômeno em questão. Os resultados descritivos usando tabelas de frequência apontam para a conclusão principal, ou seja, a crescente proliferação de estudos, especialmente qualitativos, que abordam o fenômeno e apontam à necessidade de gerar novos modelos conceptuais e de categorização das carreiras profissionais que se adaptem ao meio e às demandas contemporâneas.

Palavras-chave: Carreiras. Trajetórias profissionais. Revisão. Categorização. Modelos.

\section{RESUMEN}

Las carreras profesionales constituyen un fenómeno de estudio recurrente dentro de las ciencias sociales. El objetivo de este artículo es presentar una revisión de la literatura existente sobre el tema 
en aras de identificar cómo se estudian las carreras, trayectorias y transiciones profesionales, qué aproximaciones metodológicas se utilizan y a qué temáticas se asocian en aras de conocer a qué modelos conceptuales y metodológicos dan pie o, en su defecto, en qué modelos se sustentan.Para ello, se ha realizado una búsqueda en diferentes bases de datos indexadas dando lugar a una selección de 66 artículos que abordaran el fenómeno en cuestión. Los resultados descriptivos mediante tablas de frecuencia destacan la creciente proliferación de estudios, especialmente cualitativos, que abordan el fenómeno y apuntan a la principal conclusión de generar nuevos modelos conceptuales y de categorización de las carreras profesionales que se adapten al entorno y a las demandas contemporáneas.

Palabras clave: Carreras. Trayectorias profesionales. Revisión. Categorización. Modelos.

\begin{abstract}
Professional careers constitute a phenomenon recurrently studied in social sciences. The aim of this article is to present a review of the available literature about the subject in order to identify how careers, trajectories and professional transitions are studied, what methodological analysis are used and to which topics they are recurrently associated to finally know in what conceptual and methodological models generate or on which those are supported. To this end, a search has been made in different indexed databases giving rise to a selection of 66 articles that deal with the phenomenon in question. The descriptive results by means of frequency tables highlight the growing proliferation of studies, especially qualitative, that address the phenomenon and point to the main conclusion of generating new conceptual models and categorization of careers that adapt to the environment and contemporary demands.
\end{abstract}

Keywords: Careers. Professional paths. Review. Categorization. Models.

\section{Introduction}

Professional careers are a recurrent subject of study within the different fields that constitute the social sciences; a good example of this is the numerous studies undertaken within the frameworks of psychology, communication, business management and education (Aneas, Vilà, Pérez and Orellana, 2015; Selva, 2013; Zuperkiene \&Zzilinskas, 2008). Despite of discussingabout the same phenomenon, each field is characterized by approaching it from different aspects, formulating its own questions and generating its particular theoretical and methodological approaches with regard to professional careers. Consequently, the diversity that originates this scenario is substantial and remarkable. However, there are certain questions and challenges that recurrently appear in these different approaches as is the codification of professional careers, or in other words, the conceptual and categorical treatment given to the development of careers.

All definitions of the concept career recall to: set of activities or actions, sequentially ordered, that take place within a process. Focusing to the professional sphere, career is understood as the development of the professional or occupational activity throughoutlife; or according to the Dictionary of Human Resources Terms (Alles, 2011), as a path that a person covers along its working life.

In addition, social, political and economic changes that occurred during the last decade have gradually eroded the traditional model of professional career, that used to have, as its epicentre, the promotion, job advancement and organizational commitment 
in a context of significant economic growth (Alcaide, 2004). This conception of career seems obsolete in the contemporary context of: constant change, internationalization, offshoring, new organizational forms, economic crisis and trends to global flexibility (Selva \&Tresserra, 2013; 2014); that originates new models and classifications that highlight the necessity of having psychological contracts adapted to the particular needs of the person - and its employability - and of the organization - and its productivity and profitability - (Alcaide, 2004; Pallarès \&Selva, 2016).

All that involves a major challenge of: getting back to how professional careers are actually developed and categorized; and which personal (e.g., professional and personal expectations), social (e.g., generational), organizational (e.g., professional sectors or fields), and contextual (e.g., social, political and economic situation) factors and constraints compose and shape them in order to adapt professional careers to the needs of the current environment (Blanco, Sánchez \&Ramos, 2016; Figueroa \&Urrutia, 2016).

In this sense, knowing how professional careers are methodologically arranged and codified - considering different approaches and authorships - will allow to define the subject of study considering characteristics and proprieties conferred upon them. In other words, it will allow to discern the appropriate data for this revision from other redundant information that can be excluded and will enable to provide meaning amongst other trends.Being professional careers the subject of study, the limitations of the way of codifying data requires particular features.

Although it seems to move away from the object, in fact, when we speak about the codification task, either quantitative or qualitative, the idea of orderly succession is the most important component in the way of explaining the phenomenon. Since the imagined career takes us to the idea of a line, that can be straight, turning or ravine and that can present breaks and/or discontinuities, it is like a path wheremoving on it can be easy or difficult and that requires an effort to overcome obstacles that can imply deviations or shortcuts (which can bring back to the initial path or not). Extracting information from the line (or path) and codifying it, will permit to define it. In other words, if the line and its components are stated (roles, positions, stages, satisfaction, expectations, identity, gender, etc.) we can obtain an image, configured by different factors that, likewise, assign to the line a specific set of properties, keys and consequences.

This study presents a revision of the existing literature about the topic, aiming to identify how professional careers, paths and transitions are studied, what kind of methodological approaches are used and which themes are recurrently associated to them. This is to distinguish what conceptual and methodological models arise and/or in which models are sustained. In other words, the goal of this study is to offer, as a theoretical and methodological purpose, a mapping of the categorization models of professional careers and transitions that allow us to know the paths and constraints that characterise them and the fields or sectors which them are associated with.

\section{Method}

\section{Selection of manuscripts}

The analysed corpus is composed by scientific articles, chapters of books and doctoral thesis that approach, directly or indirectly, the professional career. The research of literature was not limited by a time range, thus we revised all the works included in the data bases: PsycInfo, Emerald, Redalyc, Dialnetand Google Scholar considering the ones that: a) approached the theme of codification of professional careers and, b) arean original work published in an academic and scientific publication. 
The searching, selecting and storage process was carried out in four steps:

a) The research of literature in the aforementioned databases, was performed by using different keywords and combinations of them. These keywords were: path; professional career; career development; methodology; management; development and/or theory of career. About the combinations, we combined words for a semantic search of two or more keywords (e.g., professional career and career development; or professional career and methodology), allowing us to gather the larger corpus possible regarding the phenomenon.

b) Preselection of the corpus according to the abovementioned criteria.

c) Individually storage of the found literature, using a pdf file and a specific naming, composed by the surname of the author and the year of publication (e.g., Garcia_2013.pdf), and a reflexive extraction of the data from the text into a spreadsheet (Excel 2003).

d) Thorough review of the collected corpus to end up the selection process. After the debugging phase (publications not directly related to the thematic or duplicates), the final corpus was composed by 66 manuscripts.

\section{Extraction}

Once the corpus was selected we proceeded to its extraction. To do so, we took into consideration the following fields: keyword; concepts and thematic of the manuscript; typology of the data used in the manuscript; codification process; questions that the manuscript answers; utility of the study; and out-coming models. In order to agree on the extraction criteria, to assure the highest level of alignment and to discuss the possible divergences, three researches performed a pilot phase of codification of 15 articles randomly selected. This pilot phase underlined the need of including an extra field in the extraction spreadsheet, called open annotations of the researcher, that allowed to record relevant aspects that the investigator considered significant regarding the manuscript.

\section{Analysis}

The corpus was analysed descriptively using frequency tables. In other words, it was analysed the relation between the text of the manuscript and the variables: methodological approach, thematic area and model. To do so, each studied variable could be disaggregated in categories and/or codes. In the case of the variablemethodological approach it was initially broken-down in three categories (qualitative, quantitative and mixed) showing the different designs of investigation and subsequently each category was disaggregated into more specific codes. For the variable thematic area werealsogeneratedseven categories, which two of them were decomposed into more concrete codes; while the variable model was directly codified in accordance with the content, without a categorization process. Finally, we carried out a reflexion about the correspondences presented by each of the studied variables (methodological approach, thematic area and model).

\section{Results}

In this section will be presented the results of the research structured by the three variables of the study: methodological approach, thematic area and model that each manuscript is based in.

\section{Methodological approach}

Throughout the literature it has been identified the usage of qualitative,quantitative 
and mixed methodological approaches. Whilst the qualitative and quantitative approaches have been divided into four (Revision, Interview, Stories and Narrative) and five (Questionnaire, Secondary analysis of data sources, Survey, Test and Scale) categories respectively, the mixed approach was divided into two categories, between triangulation inter-methods when the manuscript presented complementarity among qualitative and quantitative methods; and triangulation intramethods when different methods to collect information were combined in the same approach (qualitative or quantitative). The triangulation inter-methods are used in fourmanuscripts (e.g., Pons, Calvet, Tura
\&Muñoz, 2014), while the triangulation intramethods are used in two manuscripts of the analytical corpus (e.g., Keen \&Pease, 2016).

Table 1 shows that the most common technique of data collection is the revision (45.4\%), followed by interview (19.7\%), questionnaire and triangulation inter-method (6.1\% each), stories and secondary analysis of data sources $(4.6 \%$ each) and narrative, surveys, test and triangulation intra-method (3.0\% each). The less used techniques are the ones about scales (1.6\%). As it can be seen in the same table, the most used methodological approach is the qualitative $(72.7 \%)$, followed by quantitative (18.2\%) and mixed (9.1\%).

\begin{tabular}{ccc} 
Table & \multicolumn{3}{l}{ 1- Distribution of the analytical corpus } & by & methodological app \\
\cline { 2 - 3 } Methodological approach & Frequency & $\mathbf{\%}$ \\
\cline { 2 - 4 } Qualitative & 30 & $\mathbf{7 2 . 7}$ \\
\cline { 2 - 3 } Revision & 13 & 45.4 \\
Interview & 3 & 19.7 \\
Stories & 2 & 4.6 \\
Narrative & & 3.0 \\
\hline Quantitative & 4 & $\mathbf{1 8 . 2}$ \\
\hline Questionnaire & 3 & 4.1 \\
Secondary analysis of data sources & 2 & 3.0 \\
Survey & 2 & 3.0 \\
Test & 1 & 1.5 \\
Scale & & $\mathbf{9 . 1}$ \\
\hline Mixed & 4 & 6.1 \\
Triangulation inter-methods & 2 & 3.0 \\
Triangulation intra-methods & 66 & 100.0 \\
\hline Total & & \\
\hline
\end{tabular}

\section{Thematic area}

In the extraction process of the analytical corpus were identified, categorized and conceptualized seven thematic areas, two of them were also decomposed into different codes. Table 2 shows all of them ordered by the frequency in the manuscripts. Thus, the most recurrent category is development of professional career linked to a modulating variable $(34.8 \%)$. The categories with a more moderate recurrence are the ones related to: typology of professional career $(15.2 \%)$, and development of professional career and professional career linked to a modulating variable $(13.6 \%$ each). Finally, the subjects with a fewer recurrence are related to: professional identity $(9.1 \%)$, influential factors in developing a professional career (7.6\%), and concept of professional career $(6.1 \%)$. Additionally, within the categories that are decomposed in a set of codes outstand the development of professional career and gender (18.2\%), development of professional career and education $(9.1 \%)$ and professional career and change/transition (7.6\%). 
Table 2 - Distribution of the analytical corpus by thematic area

\begin{tabular}{lcc}
\hline Thematic area & Frequency & $\mathbf{\%}$ \\
\hline Development of professional career linked to a modulating variable & $\mathbf{2 3}$ & $\mathbf{3 4 . 8}$ \\
Development of professional career and gender & 12 & 18.2 \\
Development of professional career and education & 6 & 9.1 \\
Development of professional career and homosexuality & 2 & 3.0 \\
Development of professional career and graduates & 1 & 1.5 \\
Development of a musical professional career & 1 & 1.5 \\
Development of professional career and mentoring & 1 & 1.5 \\
Typology of professional career & $\mathbf{1 0}$ & $\mathbf{1 5 . 2}$ \\
Development of professional career & $\mathbf{9}$ & $\mathbf{1 3 . 6}$ \\
Professional career linked to a modulating variable & $\mathbf{9}$ & $\mathbf{1 3 . 6}$ \\
$\quad$ Professional career and change/transition & 5 & 7.6 \\
Professional career and decision making & 3 & 4.5 \\
Professional career and reconciliation & 1 & 1.5 \\
Professional identity & & \\
Influential factors in developing a professional career & $\mathbf{6}$ & $\mathbf{9 . 1}$ \\
Concept of professional career & $\mathbf{5}$ & $\mathbf{7 . 6}$ \\
\hline Total & $\mathbf{4}$ & $\mathbf{6 . 1}$ \\
\hline
\end{tabular}

\section{Model}

The analysed manuscripts sustain and/or are supported by different models of development and categorization of the professional career. From them we have identified the following models, Traditional Model (e.g., Pierre, 1979); Boundaryless Career Model (e.g., Arthur \& Rousseau, 1996); Protean Career Model (e.g., Hall, 1976); Kaleidoscope Career Model (e.g., Mainiero \&Sullivan, 2005); Development of Professional Career Model (e.g., Selva, 2013); Holistic Transitions Model (e.g., Wylleman \&Lavalle, 2003); and Water-polo Sportive Career Model (e.g., Pallarés, Torregrossa, Azócar, Selva \&Ramis, 2011). Additionally, we identified that, in one hand, the manuscripts from Briscoe \& Hall (2006) and Segers, Inceoglu, Vloeberghs, Bartram \&Henderickx (2008), present a combination of two of the models (Boundaryless Career Model and Protean Career Model) and, on the other hand, some of the manuscripts do not specifically present any model but they outline new proposals of conceptual and methodological archetypes of model, for that reason, we considered appropriated to include the category Prototype Model. Finally, we added a category for the manuscripts that did not present any implicit nor explicitmodel.

Table 3 shows the distribution of manuscripts for each category of model. As mentioned above, most of them do not allude to any specific model (54.5\%) and a good number of them suggest a Prototype Model $(13.6 \%)$. About the manuscripts that are based on a particular model, the one that is more frequent is the Boundaryless Career Model (6.0\%), followed by the Development of Professional Career Model, Water-polo Sportive Career Model and Traditional Model (4.5\% each) and finally the Protean Career Model, Kaleidoscope Career Model, Holistic Transitions Model and the combination of the Protean and Boundaryless Career Models (3.0\% each). 
Table 3 - Distribution of the analytical corpus by model

\begin{tabular}{lcc}
\hline Model & Frequency & \% \\
\hline Model not mentioned & 36 & 54.5 \\
Prototype Model & 9 & 13.6 \\
Boundaryless Career Model & 4 & 6.0 \\
Development of Professional Career Model & 3 & 4.5 \\
Water-polo Sportive Career Model & 3 & 4.5 \\
Traditional Model & 3 & 4.5 \\
Protean Career Model & 2 & 3.0 \\
Kaleidoscope Career Model & 2 & 3.0 \\
Holistic Transitions Model & 2 & 3.0 \\
Combination: Protean and Boundaryless Career Models & 2 & 3.0 \\
\hline Total & 66 & 100.0 \\
\hline
\end{tabular}

\section{Correspondence between model and methodological approach}

Regarding the methodological process of the different models identified previously in tables 2 and 3, for the most part of them it is used the qualitative methodological approach: revision (theoretical, critical, theoretical and practical and practical). This has particularly been reflected, for example, in the Protean Career Model (e.g., Hall, 1976) or the Traditional Model (e.g.,Peiperl \&Baruch, 1997). Others base their approaches to a more empirical view as the Development of Professional Career Model (e.g., Selva, 2013), sustained on stories; or the Holistic Transitions Model (e.g., Wylleman \&Lavalle, 2003) that uses the Triangulation Inter-methods. About the methodological approach of the manuscripts classified in the Prototype Model category, we can highlight its diversity, being the most frequently used interviews and revisions; followed by surveys, stories, tests and the triangulation of techniques.

\section{Discussion}

The presented study allows to know the codification and conceptualization of career models in the scientific-academic field in order to know from which approaches the phenomenon has been discussed andto underline the typology of paths and appealing variables exposed. The extracted results show that the qualitative methodological approach is the most used, being the most recurrent techniques the revision and interview. This result throws a first conclusion: the deepness that the qualitative approach offers, that allows to explore social relations and describe the reality as it is experienced, otherwise stated, from a holistic and phenomenological view, is usually the point of departure where the models have their foundations; and afterwards, using the breadth of the quantitative approach to generate representative and global results.

In this sense, the triangulation of methods allows to know how a professional career is developed, what variables have a relevant influence, which elements ease its evolution and what barriers or difficulties are recurrent, at the same time that, it allows to evaluate and intervene in the potential development of the career (regarding to the different realities of the organization or the sector).

The aroused relevance and interest of this phenomenon in the last decade (excluding the Traditional Model, the other models are situated in the close past or in the present), allows to sustain a second conclusion: the growing need to generate new conceptual models and categorisation of professional careers better adapted to the environment and the contemporary demands. So much so that the changes in the social, economic, politic and cultural environment of the last decades 
(Blanco et al., 2016; Figueroa \& Urrutia, 2016) (e.g., the incorporation of women in the labour market, the economic crisis or the internationalization) entailedcertain recurrences in the recent career models: placing the person as the main active agent in their development, drawing non-lineal careers and tracing paths without borders.

In short, the proliferation of scientific literature about the new models of professional paths permitted to update the phenomenon and generate new forms of intervention.

Reaping what we exposed, the mapping of the theoretical and methodological approach to the phenomenon also provides practical implications for the labour world. As a third conclusion, knowing how the labour paths and transitions or the different models mapped in this study are set and conceived permits to:

a) configure a professional development aligned with personal expectations, considering the professional sector or field in which they are framed (Aneas, Vilà, Pérez \&Orellana, 2015; Selva, 2013; Zuperkiene \&Zzilinskas, 2008);

b) offer psychological contracts that could hardly be replicated by other organizations (Pallarès \&Selva, 2016), given its high added value;

c) enhance the quality of the working life and reducing psychosocial risks associated to unfulfilled imagined expectations;

d) promote engagement and organizational commitment.

In future investigation lines, it will be required to study the professional models of career with regard to particular fields, population segments and different moments in time. In other words, facing the current macroeconomic situation, becomes relevant, for example, to focus on the professional development paths and development modelsof the graduated young people, considering both personal and phenomenological variables in that specific context that module and categorize the phenomenon.

\section{References}

Adams, E., Cahill, B. \&Ackerlind, S. (2005). A qualitative study of Latino lesbian and gay youths' experiences with discrimination and the career development process. Journal of Vocational Behavior, 66(2), p. 199-218. doi:10.1016/j.jvb.2004.11.002

Alcaide, M. (2004). La crisis del modelo tradicional de Carrera. Temas laborales: Revista andaluza de trabajo y bienestar social, 73, 223-250.

Alles, M. A. (2011). Diccionario de términos de Recursos Humanos. Santiago de Chile: Ediciones Granica, S.A.

Aneas, A., Vilà, R., Pérez, H. \&Orellana, N. (2015). Desde el Prácticum hacia la soledad. Experiencias y aportes para el desarrollo de la Carrera profesional em educación. En Raposo-Rivas, M., Muñoz Carril, P., Zabalza-Cerdeiriña, M., Martínez-Figueira, M. y Pérez-Abellás, A. Documentar y evaluar la experiencia de los Estudiantes em lãs practices. Poio, Andavira, p. 211-223.

Arthur, M. \&Rosseau, D. (1996). The Boundaryless Career: A New Employment Principle for a New Organizational Era.Oxford: Oxford University Press.

Arthur, M., Hall, D., \& Laurence, B. (1989). Handbook of career theory. Cambridge: Cambridge University Press.

Biemann, T., Zacher, H., \& Feldman, D. (2012). Career patterns: A twenty-year panel study. Journal of Vocational Behavior, 81(2), p. 159-170. doi:10.1016/j.jvb.2012.06.003

Blanco-García, M. M., Sánchez-Antolín, P. \&Ramos, F. J. (2016). Conciliación de la Vida Laboral y Familiar en Mujeres em Formación Ocupacional. Multidisciplinary Journal of Educational Research, 6(2), p. 127-151.

Blustein, D. \&Noumair, D. (1996). Self and 
Identity in career development:

implications for theoryand practice. Journal of Counseling \& Development, 74, p. 43344.

Bombuwela, P. \&De Alwis, A. (2013). Effects of Glass Ceiling on Women Career Development in Private Sector Organizations - Case of Sri Lanka. Journal of Competitiveness, 5(2), p. 3-19.

Bornat, J., Henry, L. \&Raghuram, P. (2011). The making of careers, the making of a discipline: Luck and chance in migrant careers in geriatric medicine. Journal of Vocational Behavior, 78(3), p. 342-350. doi:10.1016/j.jvb.2011.03.015

Briscoe, J. P. \&Hall, D. T. (2006). The interplay of boundaryless and protean careers: Combinations and implications. Journal of Vocational Behavior, 69, p. 418.

Campos, M. (2015). Ciclo de vida profesional del profesor universitario: La metamorfosis de la carrera docente desde el relato biográfico.Valladolid: Universidad de Valladolid.

Cohen, L., \&Duberley, J. (2013). Constructing careers through narrative and music: An analysis of Desert Island Discs. Journal of Vocational Behavior, 82(3), p. 165-175. doi:10.1016/j.jvb.2013.01.010

Davies, K. (1996). Capturing women's lives A Discussion of Time and Methodological Issues, Women's Studies International Forum, 19(6), p. 579-588. doi:10.1016/S0277-5395(96)00070-2

Debois, N., Ledon, A., Argiolas, C. \&Rosnet, E. (2012). A lifespan perspective on transitions during a top sports career: A case of an elite female fencer. Psychology of Sport and Exercise, 13(5), p. 660-668. doi:10.1016/j.psychsport.2012.04.010

Ferreira, J., Santos, E., Fonseca, A. \&Haase, R. (2007). Early predictors of career development: A 10-year follow-up study. Journal of Vocational Behavior, 70(1), p. 61-77. doi:10.1016/j.jvb.2006.04.006

Gómez-Mejía, L. R., Balkin D. B., \&Cardy, R. L. (1997). Gestión de Recursos Humanos. Madrid: Prentice Hall.

González, A. (2014). ¿Camuflaje o tranformación? Estrategia profesional de lãs mujeres encarreras tecnológicas altamente masculinizadas. Educarvol, 50(1), p. 187-205.

Hall, D. (1976). Careers in organizations. Glenview, Scott: Foresman and Company.

Hall, D. (1992). Career indecision research: Conceptual and methodological problems. Journal of Vocational Behavior, 41(3), p. 245-250. doi:10.1016/00018791(92)90026-V

Heller, L. (2011). Mujeres em la cumbre corporativa: el caso de la Argentina. Revista del Centro de Estudios de Sociología Del Trabajo, 1(3), p. 1-28.

Huang, Q. \&Sverke, M. (2007). Women's occupational career patterns over 27 years: Relations to family of origin, life careers, and wellness. Journal of Vocational Behavior, 70(2), p. 369-397. doi:10.1016/j.jvb.2006.12.003

Huberman, M. (1989). On teachers' careers: Once over lightly, with a broad brush. International Journal of Educational Research, 13(4), p. 347-362. doi:10.1016/0883-0355(89)90033-5

Ibarra, H. (2004). Career transition and change. Faculty \& Research: Working paper series, 97, p. 2-28.

Inkson, K. (2004). Images of career: Nine key metaphors. Journal of Vocational Behavior, 65(1), p. 96-111. doi:10.1016/S00018791(03)00053-8

Jiménez, M. (2009). Tendencias y Hallazgos em los estudios de trayectoria: una opción metodológica para clasificar el desarrollo laboral. Revista electrónica de investigación educativa, 11(1), p. 1-21.

Keen, C. \& Pease, H. (2016). The role of service-learning and mentoring in the early career development of a research methodologist. The Qualitative Report, 21(1), p. 117-126.

Kelly, K. \& Lee, W. (2002). Mapping the Domain of Career Decision Problems. Journal of Vocational Behavior, 61(2), p. 302-326. doi:10.1006/jvbe.2001.1858

Kumar, K., Jones, D., Naden, K. \& Roberts, C. (2015). Rural and remote young people's health career decision making within a 
health workforce development program: a qualitative exploration. Rural and Remote Health, 15(4): 3303.

Lapointe, K. (2010). Narrating career, positioning identity: Career identity as a narrative practice. Journal of Vocational Behavior, 77(1), p. 1-9. doi:10.1016/j.jvb.2010.04.003

Lonborg, S. \& Phillips, J. (1996). Investigating the Career Development of Gay, Lesbian, and Bisexual People: Methodological Considerations and Recommendations. Journal of Vocational Behavior, 48(2), p. 176-194. doi:10.1006/jvbe.1996.0017

Lozano, I., Iglesias, M. \& Martínez, M. (2014). Las oportunidades de las académicas em el desarrollo profesional docente universitario: um estúdio cualitativo. Educación XXI, 17(1), p. 157182. doi: 10.5944/educxx1.17.1.10709.

Lyons, S., Schweitzer, L. \&Ng, E. (2015). How have careers changed? An investigation of changing career patterns across four generations. Journal of Managerial Psychology, 30(1), p. 8-21.

Mainiero, L. A., \& Sullivan, S. E. (2005).

Kaleidoscope careers: An alternate explanation for the "opt-out" revolution. Academy of Management Executive, 19, p. 106-123.

Meschman, C. (2014). La narrativa de experiencias como instrumento metodológico para la indagación de la construcción de identidad de profesores em psicología. In: VI Congreso Internacional de Investigación y Práctica Profesional em Psicología XXI Jornadas de Investigación Décimo Encuentro de Investigadores em Psicología del MERCOSUR. Buenos Aires, Argentina.

Milligan, C., Kearns, R. \& Kyle, R. (2011). Unpacking stored and storied knowledge: Elicited biographies of activism in mental health. Health \& Place, 17(1), p. 7-16. doi:10.1016/j.healthplace.2009.12.016

Moen, P. \&Orrange, R. (2002). Careers and lives socialization, structural lag, and gendered ambivalence. Advances in Life
Course Research, 7, p. 231-260. doi:10.1016/S1040-2608(02)80036-3

Ng, T. \& Feldman, D. (2007). Organizational embeddedness and occupational embeddedness across career stages. Journal of Vocational Behavior, 70(2), p. 336-351. doi:10.1016/j.jvb.2006.10.002

Nuñez, P., Grande, F. \&Pedrosa, C. (2012). Nuevos retos em el desarrollo de Carrera profesional: el modelo boundaryless career. Universia Business Review, 34, 15-35.

Pallarés, S., Torregrossa, M., Azócar, F., Selva, C. \& Ramis, Y. (2011). Modelos de trayectoria deportiva em waterpolo y suimplicación em la transiciónhacia una Carrera profesional alternative. Cultura, Ciencia y Deporte, 17(6), p. 93-103.

Pallarès, S., \& Selva, C. (2016). La gestióndel contrato psicológico en una empresa multinacional de alimentos Española. Psicoperspectivas, 15(2), p. 4052. DOI: 10.XXXX/PSICOPERSPECTIVASVOL15- ISSUE2-FULLTEXT-685

Peiperl, M. \& Baruch, Y. (1997). Back to Square Zero: The Post-Corporate Career. Organizational Dynamics, 25, p. 7-22.

Pons, O., Calvet, M., Tura, M. \&Muñoz, C. (2014). Análisis de la Igualdad de Oportunidades de

Género em la Ciencia y la Tecnología: Las Carreras profesionales de lãs mujeres científicas y tecnólogas. Intangible capital, 9(1), 65-90.

Real Academia Española (2001). Diccionario de la lengua Española. Madrid: Espasa.

Reitzle, M. \&Vondracek, F. W. (2000). Methodological Avenues for the Study of Career Pathways. Journal of Vocational Behavior, 57(3), p. 445-467. doi:10.1006/jvbe.2000.1751

Reitzle, M., Körner, A. \&Vondracek, F. W. (2009). Psychological and demographic correlates of career patterns. Journal of Vocational Behavior, 74(3), p. 308-320. doi:10.1016/j.jvb.2009.02.005

Rinke, C. (2008). Understanding teachers' careers: Linking professional life to professional path. Educational Research 
Review, 3(1), p. 1-13.

doi:10.1016/j.edurev.2007.10.001

Rounds, J. \&Jin, J. (2013). Nature, importance and assessment of needs and values. In: Brown, S. D. and Lent, R. W. (Eds.). Career development and counseling: putting theory and research to work (pp: 417-447). San Francisco: John Wiley\& Sons.

Ruvalcaba-Coyaso, F., Alvarado, I. \&García, R. (2011). Identidad e identidad profesional: acercamiento conceptual e investigación contemporánea. Revista CES Psicología, 4(2), p. 82-102.

Sáez, M. L. (1995). La elección de una carrera típicamente femenina o masculina: desde una perspectiva psicosocial: la influencia del género. Madrid: Ministerio de Educación y Ciencia.

Sánchez-Olavarria, C. (2014). Los egresados de comunicación y el mercado laboral: um estudio de trayectorias profesionales.

Revista ibero americana de educación superior, 5(3), p. 40-54.

Segers, J., Inceoglu, I., Vloeberghs, D., Bartram, D. \&Henderickx, E. (2008). Protean and boundaryless careers: A study on potential motivators. Journal of Vocational Behavior, 73, p. 212-230.

Selva, C. (2013). Models of professional career of the managerial women. Universitas Psychologica, 12(4), 12371254.

Selva, C. \&Tresserra, O. (2013). La flexibilidad como herramienta para encaminarel bienestar laboral. In: Cantera, L., Pallarès, S. y Selva, C. (Coords.), Del malestar al bienestar laboral, p. 215-240. Barcelona: Amentia.

Selva, C. \&Tresserra, O. (2014). Flexibilidad Global, sinécdoque de progreso. Athenea Digital, 14(2), p. 197-202. http://dx.doi.org/10.5565/rev/athenea.1226

Spink, P. (2005). Replanteando la investigación de campo: relatos y lugares. Athenea Digital - Revista de pensamiento e investigación social, 1(8), p. 1-9.

Sullivan, S. \&ARTHUR, M. (2005). The evolution of the boundaryless career concept: examining physical and psychological mobility. Journal of vocational behavior, 69, p. 19-29.

Sullivan, S. \&Maineiro, L. (2008). Using the Kaleidoscope Career Model to Understand the Changing Patterns of Women's Careers: Designing HRD Programs That Attract and Retain Women. Advances in Developing Human Resources, 10(1), p. 32-49.

Tadeucci, M., Araujo, E. \&Ribeiro, M. (2013). Competencias social es en la estrategia de desarrollo de Carrera. Apuntes de psicología, 31(1), p. 93-99.

Vargas, M. (2014). La mujerante lacarrera académica universitaria: cuestion estras el análisis cualitativo de los datos. Revista de estúdios socio educativos, 2, p. 134-155.

Vilanova, A. \&Puig, N. (2013). Compaginar la carrera deportiva com la carrera académica para la futura inserción laboral: ¿Una cuestión de estrategia?.Revista de psicología del deporte, 22(1), p. 61-68.

Vinkenburg, C. \&Weber, T. (2012).

Managerial career patterns: A review of the empirical evidence. Journal of Vocational Behavior, 80(3), p. 592-607. doi:10.1016/j.jvb.2012.02.001

Willett, J. \& Singer, J. (1989). Two types of question about time: Methodological issues in the analysis of teacher career path data. International Journal of Educational Research, 13(4), p. 421-437. doi:10.1016/0883-0355(89)90038-4

Wylleman, P. \&Lavallee, D. (2003). A developmental perspective on transitions faced by athletes. In: M. Weiss (ed). Developmental Sport Psychology. Morgantwon, WV: Fitness Information Technology.

Zacher, H. \& Griffin, B. (2015). Older workers' age as a moderator of the relationship between career adaptability and job satisfaction. Work, Aging and Retirement, 1, p. 227-236. doi:10.1093/workar/wau009

Zuperkienè, E. \&Zžilinskas, V. (2008). Analysis of Factors Motivating the Managers' Career. Work humanism, 2(57), p. 85-91.

Zwann, K., Ter, T. F. M. \&Raaijmakers, Q. 
(2010). Career trajectories of Dutch pop musicians: A longitudinal study. Journal of Vocational Behavior, 77(1), p. 10-20.

doi:10.1016/j.jvb.2010.03.004

Dados sobre os autores:

- Clara Selva Olid: Doctor en Psicología. Universitat Autònoma de Barcelona.

- Rose Capdevila: Doctor en Psicología. The Open University.

- Miguel A. Sahagún Padilla: Doctor en Psicología. Universidad Autónoma de Aguascalientes.

- Francisco Javier Rubalcaba-Coyaso: Doctor en Psicología. Universidad Autónoma de Aguascalientes.

- Alba Navarrete Briansó: Máster Universitaria en Psicología General Sanitaria. Universitat Autònoma de Barcelona. 